\title{
RESETTLEMENT PROBLEMS AND POLICIES ${ }^{1}$ )
}

\section{RAINER SCHICKELE}

Food and Agriculture Organisation of the United Nations, Rome, Italy

\section{Contents}

1 INTRODUCTION

2 SCOPE FOR LAND DEVELOPMENT AND INTENSIFICATION OF LAND USE $\ldots . \quad \ldots \quad 240$ Reopening of the settlement frontier . . Improvement of the old agricultural land . .

$\begin{array}{lllllllllllllll}3 & \text { The AgRicultural LAG } & \ldots & \ldots & \ldots & \ldots & . & \ldots & \ldots & \ldots & \ldots & \ldots & \ldots & 242\end{array}$

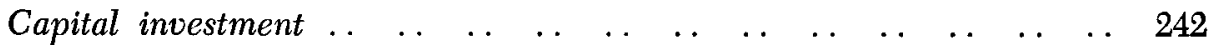

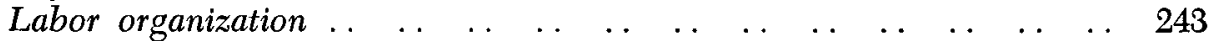

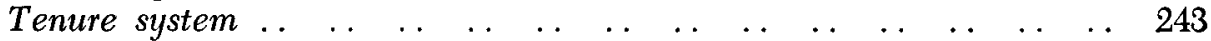

Farm size patterns ..

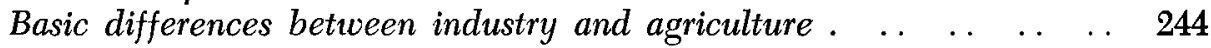

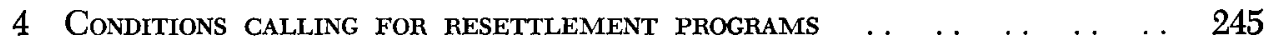

5 MEASURES FOR ENLARGING UNDERSIZED FARMS . $\quad \ldots \begin{array}{lllllll} & \ldots & \ldots & \ldots & \ldots & \ldots & 245\end{array}$

Government allocation of land to undersized holdings ..

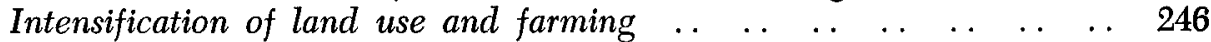

Consolidation of holdings, resettlement and land improvement .. . . 247

6 MeASURES FOR SUB-DIVIDING LARGE ESTATES $\ldots$.

Problems of establishing viable holdings ..

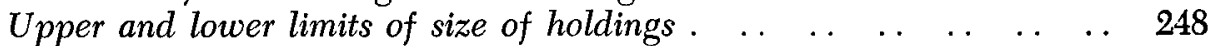

Eligibility of settlers . ..

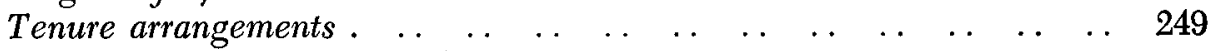

7 THE CASE OF COOPERATIVE FARMing EXAMINED

Characteristics of large centrally operated estates $\ldots$.

Mobilization of under-utilized farm labor ..

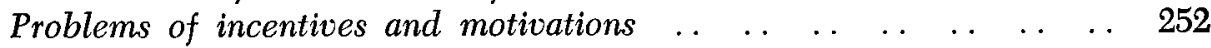

$\begin{array}{llllllllllllllllll}\text { SuMMARY } & . & \ldots & \ldots & \ldots & \ldots & \ldots & \ldots & \ldots & \ldots & . & \ldots & \ldots & \ldots & \ldots & \ldots & 253\end{array}$

\section{INTRODUCTION}

The technical-scientific and business-economics problems of how to develop land and use it to best advantage have been quite fully explored during the last 50 years, and good methods have been found to solve them. Modern soil surveys give us fairly reliable data on use-capability of soils, we know a good deal of nutrient requirements of plants, hydrological surveys tell us about potential water supplies, irrigation and drainage engineering has given us effective control over water as a production factor in agriculture, and production economics provide us with elaborate techniques for determining the optimum combination of factors for maximum farm income.

We are much less advanced in finding solutions to the human and institu-

1) Received for publication June 6, 1957. 
tional problems of putting our technical knowledge into effect, of motivating people to apply this knowledge in the concrete farming practices and organization of the agricultural production process. The hardest problems which economic policy for agricultural development faces are problems of incentives and motivations of farmers. These incentives and motivations are strongiy influenced, and can be deliberately guided, by institutional arrangements such as tenure conditions, credit facilities, cooperative, communal and governmental services, and the socio-political structure of society. The very purpose of public policy in modern democratic society is to bring about changes and adjustments in institutional arrangements which will offer powerful incentives to individuals and mobilize their motivations so as to release pent-up human energies into channels of activities that are conducive to economic development and community welfare.

The settlement of farm families on new lands, and the resettling of farmers in old established farming areas require that farmers are motivated so that they really want to develop the land, and that incentives and rewards are offered which will bring forth the best efforts of the farmers and their families. The degree of success of settlement and resettlement projects depends largely on the efficacy with which policy measures and institutional arrangements succeed in eliciting appropriate farmer motivations and in offering incentives commensurate with their best productive efforts.

The land consolidation and resettlement programs new beginning to come into their stride in Europe, and in which the Netherlands has set such an imposing example, are a most promising approach for opening the door to agricultural progress. They act as a lever for inducing long overdue changes in production methods and as a stimulus to farmers for abandoning obsolete traditions and attitudes.

\section{SCOPE FOR LAND DEVELOPMENT AND INTENSIFICATION OF LAND USE}

A brief review of the scope for land development and intensification of land use is useful to gauge the importance of settlement and resettlement problems in the future.

\section{Reopening of the settlement frontier}

During the depression of the Thirties' people in the Western world had the feeling that the settlement frontiers had come to a close, that most of the areas in the world suitable for agricultural settlement had been brought under the plow, and that the only hope for mankind to escape the pressure of population on the food supply lay in increasing yields on land new in production and reducing the rate of population growth.

As recently as 1951, a well-known historian, Professor W. P. Webb, wrote an article entitled "Ended" : 400 Year Boom - Reflections on the Age of the Frontier" 2) in which he predicted dire results from the fact of the close of the settlement frontier. He argued that deepgoing changes in the socio-political structure of society will have to take place for mankind to adjust itself to the present limits of living space.

2) Harper's Magazine. New York, October 1951. 
Since the end of World War II, however, we can detect a remarkable change of heart on the part of agriculturists and statesmen, particularly in Asia, Africa and Latin America. Modern technology in transportation and communication, land clearing methods, irrigation and drainage engineering, soil fertility and fertilizer production have given us a new look at the land and water resources in many parts of the world. Moreover, the rate of capital formation has so far outstripped the rate of population increase that capital is becoming progressively cheaper relative to labor as a factor of production. All these things combine to make it possible for millions of additional hectares to be reclaimed and prepared for agricultural use.

The conditions under which these new lands will be settled by farm families, however, will be largely determined by positive government policies since the "spontaneous" privately sponsored settlement activities of the 19th Century have almost come to a close. The new land development schemes require substantial advance planning and long-range capital investment. The aspirations of settlers' families have also changed, along with the welfare responsibilities of modern democratic states, so that the deprivations of one ond sometimes more generations of settlers so typical in the past are no longer tolerated. The development and settlement of new agricultural lands, therefore, will be largely a matter of government sponsored and guided projects involving heavier capital investments and more intensive systems of land use than in the past.

\section{Improvement of old agricultural land}

As to the order of magnitude of future increases in agricultural production, the improvement of old agricultural lands and the intensification of its use, however, holds promises much greater than the re-opening of new frontier lands. Land improvement even in the western countries, but most decidedly in the under-developed regions of the world, have greatly lagged behind what would have been technologically feasible and economically justifiable. Even in the industrially advanced areas of the world like North America and Europe, there are large areas of agricultural land which could be irrigated but are not, which could be drained but are not, which should be reforested but are not. There are regions where the land could be farmed much more intensively if there were more adequate farm buildings, fences for controlling the grazing of livestock, reads and communal services which have become important production factors in modern agriculture.

Besides such more permanent investment in land improvements, there are many areas of well-established agriculture, where fertilizer use, more intensive crop rotation, mechanization, greatly expanded livestock production and diversification in the organization of the production process could make for a much fuller use of farm labor as well as land resources and lead to higher levels of productivity and farm income.

If we ask ourselves why all these land improvements have not been made, why this higher intensity of land use has not been achieved in large areas even of the United States, Canada, England, Germany, France, and Italy, just to mention a few highly developed countries, I believe we must find the answer in the obsolete tenure systems and settlement patterns which to such a large extent govern the behaviour of farmers and limit their opportunities 
of taking advantage of technological and economic progress which has been so dazzling in the industrial and trade fields.

Throughout the world we observe that in order to introduce modern farming methods, undersized farms would have to be increased in size, large estates would have to be broken up and subdivided into economically sized family farm units, share cropping systems would have to be abandoned and replaced by cash rents or owner-cultivatorship, and various cooperative organizations would have to be created in order to apply modern knowledge and certain economics of scale to agricultural production.

In very broad strokes this sketches the sets of conditions out of which the need for resettlement of farm families and for changes in tenure arrangements in old established farming regions arises. And it is to this problem that I shall devote myself in this discussion.

\section{The agricultural LAG}

It is useful to ponder about the reasons for the phenomenal sweep of "industrial reform" in the urban sectors of the economy in Western countries without which the rapid rate of growth of industry and commerce could not have been achieved, and the reasons for the stagnation in the agrarian structure, for the lack of "agrarian reform" which has retarded progress in agriculture. An understanding of the reasons for this disparity between industry and agriculture should help us in visualizing the kind of policies which promise to assist agriculture in catching up with other sectors in economic development.

\section{Capital investment}

The formation of capital and the rate of investment in industry and trade have received a tremendous boost by the innovation of the corporate structures of enterprises. The establishment of corporations greatly influenced the incentives of savers to make their often modest individual savings available to corporations for long-term capital investments. The limited liability privilege granted by law to the owners of stock sheltered the enterprise managers and stockholders from many serious risks. The corporate structure made it possible for the managers to concentrate on the technological development of their enterprises, again without assuming dangerous risks for their own person. The whole institutional structure of modern industry encouraged the development of a technologically oriented and professionally motivated corps of managers and technicians who found in the systematic application of science to the development of industrial production processes the road to success.

Practically none of the institutional arrangements characterizing the corporate structure of industry have been made available to agriculture; nor are they directly applicable to agricultural production processes. Therefore, the problem is to find alternative arrangements for supplying agriculture with sufficient capital at favorable terms, and for sheltering farmers from a good part of the risks involved in changing over to new farming techniques.

In agriculture, neither farmers nor outside investors are protected by limited liability as is the case under corporate law. The financial turn-over is much slower than in industry. No corps of professional managers has developed, at least not outside the communist orbit. The organization of production units depends largely upon family enterprises whose main source of capital comes 
from the re-investment of a small part of commonly meager earnings. The commercial banking system has developed its credit facilities in accordance with the need of industry and commerce, with the result that the conventional credit terms do not meet the needs of farmers and the nature of the agricultural production process - all of these things combined to starve agriculture for want of capital in comparison with industry. Cooperative credit and supervized credit tied in with technical and farm management advice offer great promise for overcoming the lack of capital in agriculture.

\section{Labor organization}

In industry, the organization of workers into labor unions strengthened the bargaining power of labor and provided managers with a powerful incentive to increase the efficiency of labor use. As wages rose, employers were forced to protect their profits by using labor more economically and combine it with more and more capital to attain high levels of production efficiency. Again this incentive to increase the productivity and the investment of capital in agriculture has been notoriously lacking throughout most of the agricultural regions particularly in the under-developed countries.

The nature of the agricultural labor supply is such that neither the head of the farm family, nor the landlord of a group of tenants, nor the manager of a centrally operated estate has any forceful incentives to using labor efficiently. With only few exceptions, farm labor is not organized and has a very weak bargaining position vis-à-vis the employer, the landlord or the head of the farm family. Hence, farm labor is comparatively cheap, undervalued, and under-utilized in terms of potential efficiency.

In some of the highly industrialized western countries this bargaining power of farm workers has been strengthened by the fact that rapidly expanding industry has absorbed not only the farm population increase but actually has reduced the number of workers employed in agriculture over the last 50 years. This, however, does not hold for the bulk of workers in agriculture in most countries of the world. Again, I want to emphasize that the motivations of farmers for using labor efficiently are much less strong than those of managers in industry where labor is organized and wages are high.

\section{Tenure system}

Also the nature of the tenure system in much of world agriculture is such as to offer but little incentive for technological and economic progress. There are large areas in southern Europe, in the Near and Far East, in Latin America where share tenancy is still a dominant characteristic, and where landlords have little interest in improving the agricultural production system and belong to a class essentially oriented toward urban interests. Under these conditions one cannot reasonably expect share croppers and tenants to be keen on innovations in production methods, to risk even a small part of their insufficient income on pursuing unknown ways of doing things. As one farm leader has put it : for them, farming is largely a set of inherited motions.

Similarly, since landlords under these conditions usually have control over large areas and large number of tenant holdings, the sum of the rents they receive is an income quite large enough to maintain their accustomed standard of life and in addition to yield funds the greater part of which they invest 
in industrial and other non-agricultural business ventures. In fact, their income from non-farm investment often far exceeds the returns from their land holdings. Again, one cannot expect any strong motivations on the part of this landlord group to improve agriculture.

\section{Farm size patterns}

In most agricultural regions the farm size pattern and the lay-out of farms was established many generations ago during times when farm machinery still was very primitive and the only source of energy where the muscles of man and animal. The extreme fragmentation of holdings still present today in many areas was no particular handicap as little as 50 years ago while today it represents a serious obstacle to efficient farming. There are many areas where farm sizes are very poorly adapted to soil and topografic conditions, for instance where fertile alluvial plaines are found in large extensively managed estates while the surrounding hills are overcrowded with undersized subsistence farms poorly supplied with capital, technical advice, educational and cooperative facilities, and where as a result the land is overworked and is deteriorating fast through erosion, fertility depletion, and deforestation.

I could list a host of individual examples showing obvious and serious maladjustments in farm size patterns, tenure conditions, capital supply, and the lack of desirable motivations and incentives on the part of farmers, landlords, and estate managers. It is this widely prevalent set of conditions out of which arise the need for resettlement and agrarian reform in the old established farming areas in the world.

\section{Basic differences between industry and agriculture}

In looking for solutions of these problems and for constructive policy measures to implement them, a warning is necessary against blindly imitating methods used in industry and commerce. There are many basic differences between industry and agriculture the roots of which lie in the fact that agriculture depends upon biological processes which are much less susceptible to labor division, large-scale organization and impersonal management methods than is true in industry. The very fashionable attempts of imposing industrial methods of organization upon agriculture rest upon a serious fallacy that what has proven effective in industry must also work in agriculture. Because of the dominance of biological processes in agricultural production the role of individual incentives and motivations will always be much greater and critically important than in industry. There is a deep wisdom in the old saying that the eye of the master fattens the cattle.

I believe that even the most rigorous application of scientific methods to agricultural production will lead to the conclusion that agriculture is an occupation in which the attitudes and motivations of people as well as their production methods should be those that are characteristic of relatively smallscale craftsmanship, in which the limits of economies of scale are soon reached, and where large-scale organization with the attendent impersonalization of relationships between the worker and the endproduct of his activities find only very limited applicability without serious losses in efficiency.

I would point to the comparative lack of success of agricultural production under collective large-scale forms of organization in contrast to industry. I could 
cite many specific examples which show that a well-organized and adequatesized family farm enterprise is technically and economically more efficient in the use of productive resources than even well-managed large-scale enterprises mainly depending upon hired workers. Paranthetically I might add that there is a good deal of evidence, that even in some important industries the size of the operating unit has increased much beyond the optimum size from the stand point of efficiency.

These considerations are directly relevant to the specific problem of resettlement and tenure improvement in large areas of world agriculture.

\section{Conditions CALling FOR RESETTLEMENT PROGRAMS}

We shall now turn to the practical problems of resettlement planning for the purpose of raising agricultural production to higher levels of efficiency, and farm families to higher levels of living.

There are vast agricultural regions throughout the world where the existing size-distribution of farms does not permit effective application of modern farming techniques, where many farms are too small to support a farm family at decent living standards, and where large areas could support many more farm families at acceptable living standards than they are supporting now. Resettlement, therefore, constitutes an adaptation of farm size patterns to the needs of agricultural progress and involves an improvement in the agrarian structure in the direction of mobilizing farmers' motivations by offering appropriate incentives and rewards to bringing forth their best efforts in production and facilitate the full exercise of their managerial function.

There are three fairly distinct types of resettlement problems :

a the enlargement of undersized farms into viable operating units which involves the displacement and subsequent resettlement of farm families;

$b$ the rearrangement of boundaries of ownership and operating units and the consolidation of fragmented holdings which are necessary for vigorous progress in agriculture; and

c the subdivision of large estates and the creation of additional farming units of viable size which offer opportunities of settling new families which have been displaced elsewhere.

\section{MEASURES FOR ENLARGING UNDERSIZED FARMS}

In contrast to settlement problems of newly reclaimed agricultural land, resettlement problems on old land face the established traditional ownership and tenure patterns dating from centuries past. Today, modern governments find it often easier to expropriate large estates and distribute the land to tenants and farm laborers, than to change the size distribution in areas of small holdings, such as the minifundia in Latin America. In fact, most governments who have distributed land to farmers found themselves under great pressure to allocate insufficient land areas to farm families and thereby creating problems of undersized, non-viable holdings. One feature of policies dealing with enlarging undersized farms is that they are much less dramatic, are showing results more slowly and therefore find political support less readily than policies aimed at subdividing large estates. 


\section{Government allocation of land to undersized holdings}

The most direct method is for the government to acquire a number of adjacent small holdings, recombining them into units of viable size and reselling or leasing them to eligible farm families of the area. This, of course, involves also the resettlement of the displaced farm families elsewhere in agriculture or some other occupation. It is obvious that under normal conditions in democratic regimes, conditions will be rarely such as to make this policy feasible on any large scale.

A milder and more gradual program is for the government to grant a purchase option to undersized farmers for nearby land coming into the market, and to supplement this option by appropriate credit facilities. The government may also restrict this option to some public agency which would be instructed to re-sell the acquired land to undersized farmers at favorable terms for the enlargement of their holdings. To be rational such a policy should be restricted to the purchase only of units which are either well below an adequate size, or well above it. There are, of course, many variants of this policy possible. For instance, the government may establish its right to approve any sale of agricultural property and determine eligibility requirements of the buyer in such a way as to bring about an improvement in the farm-size distribution. A further application of this general principle is the prevention of subdivision of farm holdings by inheritance into uneconomic units by establishing a minimum limit of farm size and by providing for alternate means to satisfy the claims of coheirs.

By far the most common measure for enlarging undersized farms is the partial distribution of large estates, or of newly reclaimed and improved land, to nearby farmers on undersized holdings for purposes of enlarging their operating unit. This has been quite generally and successfully applied in those European countries where the government has undertaken land distribution and resettlement programs.

\section{Intensification of land use and farming}

Another type of measure for making undersized farms economically more viable should be mentioned, although it does not necessarily involve the physical shifting of the residences of farm families. That are measures concerning the encouragement and support of cooperative services, technical advice through extension and education, and improvements of such communal services as roads, electricity, telephone and communication, credit and marketing facilities. All these things make it possible for the small farmer to intensify his production, to realize more income from his products, and to take advantage of economies of scale through the cooperative use of certain types of machinery, storage and marketting facilities. Some outstanding examples of this type of measures can be found in the Netherlands, the Scandinavian countries, Switzerland, and in certain areas outside of Europe as well.

I should like to emphasize that these governmental, cooperative, and communal services are also most important where physical resettlement of farm families is involved, since the uprooting of farmers and the acquisition of new land create many new problems. 


\section{Consolidation of holdings, resettlement and land improvement}

In many of the areas in Europe where enlargement of undersized farms is needed, there also exists the problem of fragmented holdings. It is, therefore, much to the credit of the leaders in the respective countries to have seized upon any opportunity which presented itself for consolidating fragmented holdings, to go a decisive step further and improve the farm size pattern in the process. Modern thinking in Europe is crystallizing in the opinion that any major project for consolidating fragmented holdings should be extended to include enlargement of undersized farms, adjustments in the lay-out of farms, moving the residence of some farm families out of congested villages into the country, building of roads, drainage and irrigation systems where needed, and planning the project area so as to give the farmers the incentive and the opportunities to modernize their production methods to the benefit of the community and of their own living standards.

The European Commission on Agriculture has a Working Party on Consolidation of Fragmented Holdings, which is served by the FAO Secretariat. This Working Party has been very active in canvassing the European countries on their experiences with consolidation and related land improvement schemes and will report to the ECA this fall at its meeting in Vienna. This overhauling of farm size patterns, tenure arrangements, lay-outs of farms and roads in old established agricultural regions is really an amazing achievement, particularly since in most of the areas where such schemes are in operation there is very little land from large estates or from large reclamation schemes available to case the process of enlargement of undersized farms.

By a tours-de-force which has impressed the world but has set the heads of conservative economists wagging, the Netherlands have wrested thousands of hectares of fertile land from the sea through their polder schemes. These new lands have helped greatly the improvement of the farm size and tenure structure in other areas by providing new settlement opportunities to farmers. The Netherlands Government deserves high praise for the very excellently conceived and well-executed consolidation and farm enlargement programs in the old areas, as well as for the settlement programs of the polders.

\section{Measures For SUb-Dividing LARGE ESTATeS}

In Asia, the Near East, Latin America, and some European countries like Italy and Spain, large landed estates are on trial. Public opinion is growing that a wider distribution of land ownership among farmers is necessary both for increasing agricultural production and for reducing social and political unrest. The most sweeping measures for re-distributing land to farmers have been taken in Japan where this process is virtually completed. But a number of other countries are also in the process of implementing similar agrarian reforms. A review of these measures can be found in the "Second Progress Report on Land Reform", just issued by the UN in cooperation with FAO and ILO.

The subdivision of large estates also entails a certain amount of resettlement of farm families, and appropriately so since such a major reform in the land tenure structure offers an excellent opportunity to establish farm size patterns and tenure arrangements required for agricultural progress. 
In many cases, however, great difficulties are encountered in bringing about these adjustments in a well-planned manner. The problems involved can best be visuallized by considering two contrasting situations : 1) where the land to be redistributed is already occupied by individual tenant families; and 2) where the land has been centrally operated by an estate manager with hired laborers and share croppers. In the latter case the task of resettlement assumes a much greater proportion than in the former.

\section{Problem of establishing viable holdings}

A factor of great importance is the density of the farm population relative to the productive capacity of the land. Where the population is dense there is danger of distributing the land in too small holdings which creates all the problems of undersized farms.

This danger is not easy to avoid, where masses of landless farm workers are clamoring for land. In principle, the most realistic solution must be found in a compromise between what economists may determine as the optimum size from the farm management viewpoint, and what the socio-political claims of farmers for land demand. There are four important means for approaching economic units under such conditions : 1) improving the land by irrigation, drainage, terracing, deep-plowing, etc. ; 2) providing credit and technical assistance for intensive diversified farming with emphasis on high-value crops and livestock production; 3) developing cooperative services for the use of specialized machinery and for marketing with emphasis on product quality and reducing trade margins ; 4) procuring alternative employment opportunities within and outside agriculture.

In the process of redistribution of land, a balance should be struck between the establishment of new land units, and the allotment of land to undersized holdings in the area. In many cases it is almost a necessary requirement to complement a program of redistribution of land with a land development and improvement scheme. Among the various countries that have embarked upon a policy of land redistribution, resettlement, and land improvement, Italy offers one of the best examples of a well-planned and well-balanced program.

\section{Upper and lower limits of size of holdings}

Land redistribution and resettlement constitutes a major operation on the existing agrarian structure and, therefore, should take all possible precautions that the salutory effects are assured to continue into the future. For this reason it may be advisable to establish upper and lower limits for the size of holdings, with provisions discouraging or preventing the creation of undersized farms on the one hand, and the accumulation of large tracks of land into single hands on the other. A policy of this kind should fully realize that the land surface measure is only a partial indicator of farm size in the economic sense. The guiding principle for establishing such limits should be couched in terms of gross-value of production under average management and a well adapted farming system.

The lower limit might be geared to the living requirements of a small farm family not yet matured to its full productive stage or well beyond the peak of its labor productivity.

As to the upper limit one might consider establishing it at a level of re- 
sources that could be handled by a large family in its best productive stage, supplemented in its labor force by a small number of year-round hired workers and the necessary amount of seasonal workers during peak periods of labor requirements. Upper and lower limits thus determined should give ample leeway to diversity of farm sizes which would suit the needs of various types of families and managerial skills. In addition, of course, there can be a great diversity in the degree of intensity of farming within each size group to further allow for wide differences in size and skills of individual farm families.

The establishment of a lower limit may necessitate making specific provisions for alternate ways of guiding the inheritance process. Fragmentation of holdings below the lower limit through inheritance should be definitely discouraged or prevented.

\section{Eligibility of settlers}

In many resettlement projects there are more applicants for land than there is land to go around for distribution. Hence, some selectivity of settlers becomes necessary. Here, like in the problem of determination of farm sizes, economic efficiency considerations should not be the only ones to determine eligibility. We are dealing with human beings, with families who often have very strong loyalties to a region or a community, and some have alternative opportunities while others have not. For instance, an old farmer and his wife may not be capable to adjust themselves to another environment and take up another occupation. Their claim for a farm should be recognized in spite of the fact that their work capacity is on the decline. In practical terms, the most important criteria for eligibility should include general moral character, industriousness, degree of self-discipline that families have manifested in the past, and serious handicaps in shifting into other occupations. These are, of course, criteria very difficult to evaluate objectively and apply administratively. Still, the degree of success of the resettlement program may well depend upon the human wisdom exercised in the selection of settlers. Administrative regulations should be drawn up as closely as possible to meet this basic principle. Again, the Netherlands have set an excellent example in their circumspect policy of settler selection which includes modern procedures of vocational guidance and aptitude tests.

One of the great difficulties in resettlement programs rest on the fact that modern democratic states cannot avoid assuming a good share of responsibility for the fate of those farm families who cannot be accomodated in the resettlement scheme. From the view point of the economy as a whole, effective provisions including financial assistance to help surplus families to locate and adjust themselves elsewhere either within agriculture or outside are bound to represent a much better public investment than any savings that the government might be able to achieve by not looking after these people. The shirking of this responsibility on the part of the government is bound to lead to undersized farms and the resulting retardation of agricultural progress, or to frustration and unrest on the part of the displaced families.

\section{Tenure arrangements}

An important policy decision deals with the type of tenure arrangements most likely to stimulate agricultural progress. 
On the part of farm families themselves, everywhere throughout the world there seems to be an almost uniform preference for the ownership of land in independent operating units. Even within a pattern of owner-cultivatorship, however, there are a number of things which are clearly the responsibility of the government, i.e. of the community as a whole. For instance, absolute feesimple ownership carries serious dangers for land speculation, accumulation of lands in the hands of a few and corollary dangers of neglect of land and inefficient husbandry. Governments should be advised to explore means of safe-guarding a well-balanced farm size and tenure structure once it has been established by reserving certain rights, particularly concerning the disposal of land. There are many legal ways in which this can be done. I am inclined to think that the simplest means of reserving to the government an option to buy land, or the right to approve the new buyer, may in many cases be preferable to more complicated measures involving land taxation and other control devices.

In a number of cases, state-tenancy on long time and perhaps even inheritable leases may be found suitable. Here, specific provisions must be made for buildings and permanent land improvements either by permitting the tenants to own the farm buildings and improvements, or by effective compensation for unexhausted improvements made by tenants. Again, the attitudes, motivations and incentives of farm families should form a major consideration in the determination of the measures adopted. I cannot emphasize too strongly that the main significance of tenure arrangements lies in their effect upon the behaviour and motivations of farmers. Under any set of physical and economic conditions, that type of tenure will be the best which will stimulate farmers to put forth their best efforts and develop their managerial skills to the limit of their innate capacities.

In recent years, particularly in several Latin American countries, suggestions have been made to encourage the owners of large estates to rent their land to tenant farmers at favorable rental terms and with adequate security of occupancy. This would lead to a much more intensive land use and farming system, would give greatly increased opportunities to farm laborers and smallholders from overcrowded areas to become full-fledged operators of viable farm units, and would increase the income to the landlord as well as the living standard of the cultivator. If such a policy could be made to work on a large scale, many difficult problems characteristic of land reforms could be avoided. However, if we want to be realistic about the scope that such a policy can be expected to attain, the prospects seem rather dim because of the nature of the attitudes of the landlords on the one hand, and of the very poor, usually illiterate farmers with a very weak bargaining position on the other. I fear, that by holding out unsubstantiated hopes to achieve land improvements, tenure adjustments and resettlement along these lines, progress in this field will only be retarded rather than hastened. It might well be, however, that in conjunction with a nucleus of more direct tenure improvement and resettlement programs, an appeal to landlords along the lines suggested might bring forth significant results under certain social and political conditions. 


\section{The CASE OF COOPERATIVE FARMLNG EXAMINED}

Under two types of conditions the interest in cooperative farming as a form of settlement or resettlement is gaining attention: where the population density is so great as to result in extremely small farm units, and where the farm population is comparatively unskilled and not used to individual operatorship and voluntary cooperation. Under these conditions some people feel that large centrally operated farm units under the control of farmer cooperatives might be more efficient than independent very small holdings of the family farm type. This issue is becoming increasingly important in the Far East but also in some areas in the Near East and Latin America ${ }^{3}$ ).

\section{Characteristics of large centrally operated estates}

The cooperative farm is conceived as a centrally operated estate in which the members hold stock in the land and other permanent improvements but where land and equipment is pooled and where the rewards of individual farm families are determined by their labor contribution to the enterprise. This type of farm organization receives additional appeal as it seems to offer the advantage of industrial production processes leading to economies of scale.

It is argued that on such cooperative farms the fields can be laid out for modern machine operation, crop rotations can be applied according to requirements of soil, climate and economic factors throughout the farm unit, improved seed and fertilizers can be introduced much faster than would be true in individual small holdings, and higher standard of quality and uniformity of product can be achieved. Moreover, it is easier to develop in a short time a small corps of well-trained managers than to educate large masses of individual farm operators to comparable levels of skills and technical knowledge. It is also easier to make necessary land improvements such as irrigation and drainage, land levelling, erosion control structures, fences and roads, if one does not have to overcome the obstacles of respecting the ownership boundaries of small holdings and the many difficulties of organization presented by dealing with large numbers of independent farmers.

Mobilization of under-utilized farm labor

Another important advantage claimed for such cooperative farming enterprises is the possibility of mobilizing the large amount of under-utilized labor available in over-crowded areas. During the slack seasons, for instance, a good part of the labor force can be organized and used for the construction of roads, dams and canals, houses, sanitary wells, community centers, hospitals, and many other village improvements. This creation of social capital, of course, is bound to increase the productivity in agriculture as well as the real income and living standards of the farm population.

Such mobilization of under-utilized farm labor can also be achieved under small holdings, but there one depends largely upon voluntary cooperation of independent farm families, upon very persuasive leadership in organizing such voluntary labor for general village and land improvements, and the whole financing and organization presents many more problems than under cooperative farming conditions.

For instance, it has been the experience with Shramdan (self-help) programs

3) See the UN-ECOSOC Report by the Secretary-General to the 23rd Session on "Cooperatives", of which Chapter 3 was prepared by FAO and contains a brief discussion of cooperative farming. 
in India that although in a number of cases these voluntary labor contributions have produced impressive results they have tended to disintegrate after a year or two and in some cases have never gotten a good start.

It is quite clear that in areas where leaders feel a strong pressure for showing quick results in agricultural progress the idea of cooperative farming finds considerable appeal. Continental China at the present offers a most farflung example of such a policy. The recent Indian Mission to China appears to have been quite impressed by what they have seen there ${ }^{4}$ ).

It should be mentioned that in contrast to the collective farms in Russia, the cooperative farms in China maintain at least initially and in some areas the symbol of individual land ownership by assigning specific pieces of land to individual members of the cooperative or by issuing shares of stock representing their individual ownership in the land of the cooperative.

\section{Problems of incentives and motivations}

I have already mentioned earlier that there are relatively narrow limits for achieving economies of scale in agriculture. Hence, from the technical production viewpoint, such farming cooperatives need not be very large to exploit whatever opportunities there are in large-scale production methods. I believe, however, that the greatest difficulties of developing cooperative farming units on a large scale lie in the fields of farmer incentives and motivations.

Farmers inevitably will develop an attitude toward the land, the crops and the livestock, typical of a hired worker who has only a rather remote personal interest in the ultimate outcome of the production process and the overall efficiency of the enterprise. He receives his income in the form of wages and in some cases, of dividends on a stock share he owns in the land, which he cannot identify with his own individual efforts and care. The biological nature of the production process in agriculture requires a rather intimate relation between the farmer and his crops and livestock in order to adjust his work closely to the rythms of climate and growth processes in plants and animals. There are many decisions in farm management particularly as to timing of certain important operations which are very difficult to routinize.

Within these limitations, management must face the fact that it has to deal with a rather impersonal attitude of the worker towards his job, as is true in industry. In order to achieve the required motivations of people to do a good job, one must depend upon externally induced group discipline rather than upon the self-discipline of individual operators. The patterns of motivations and incentives in industrial enterprises are very basicly different from those in agriculture and are much more readily adaptable to the needs of industrial production processes than they are to agriculture.

There is also the issue of the degree and kind of compulsion involved in the large-scale application of cooperative farming as a resettlement and agrarian policy. I believe that the strong emphasis on completely voluntary cooperatives prevalent in western countries is not realistic in many areas in other parts of the world.

A good deal of government sponsorship and supervision in the creation of cooperatives appears inevitable, and in order to give cooperatives a reasonable chance to get off to a functioning start it may often be necessary to

4) Report of the Indian Delegation to China on Agricultural Planning and Techniques. Government of India, Ministry of Food and Agriculture, New Delhi, July-August 1956. 
make membership a condition for receiving land, at least for the first few years. Where this is the case, however, a very genuine attempt should be made to have these mandatory features used only for a transitional period, to be gradually relaxed as the attitude of members is adjusting itself to cooperative activities. In order to hasten the active and responsible participation of members in cooperative affairs much effort should be spent on the local level in training members to assume responsibilities in the running of the cooperatives. Ultimately the very essence of cooperation remains the voluntary association of members in activities serving their mutual and individual benefit. If this spirit and ultimate goal is lost, we deal no longer with a cooperative organization, but with a collective farm autocratically controlled without a genuine participation of the members in the purposes and decisions of the enterprise.

Paranthetically it should be recognized that modern corporate industry in the Western countries is organized precisely on such authoritarian lines. The main point I want to stress here is that it obviously has brought most impressive results not only from the viewpoint of production efficiency but also concerning the development of democratic institutions, the recognition of the dignity of the individual, and freedom of the industrial worker. There is room for serious doubt, however, whether agriculture lends itself to the development of high degrees of production efficiency and of individual dignity and democratic institutions under the typical form of industrial organizations just described.

Life is complex, and the issues we are dealing with should not be answered categorically, should not be conceived as being solved either completely through the independent family farm approach or through cooperative farming. There is room for all kinds of graduations between these extremes. It might be most constructive to assume that in each country and in each major farming area, a particular tailor-made combination of the individualistic and the cooperative principles would bring forth the best results and should be determined through trial and error, through an experimental attitude in policy formulation.

\section{SUMMARY}

I should like to summarize the essence of these considerations very briefly as follows :

1 The frontiers of settlement are being reopened in many parts of the world. Technological advances in irrigation and drainage, land clearing, tillage and soil fertility improvement, road construction and communication techniques have raised the assessment of land use capabilities so that lands formerly thought unsuitable for agriculture are now found capable of supporting farm settlements.

2 These same technological advances have rendered farm size patterns and farm lay-outs and many aspects of the agrarian structure in old agricultural areas obsolete. Agriculture is badly lagging behind industry and commerce in economic progress and levels of living. Farmers have been starved for capital, many lands are under-improved, the intensity of land use and farming systems is lower than it should be, many tenure arrangements thwart the exercise of initiative and managerial skills of farmers and dampen their incentives. Some lands are over-crowded with undersized farms, other areas are much too extensively managed and under-populated. There are large areas in most countries where resettlement and agrarian reforms are necessary to accellerate progress in agriculture.

3 In formulating resettlement and agrarian reform policies, there is danger in succombing to the fallacy that what is good for industry is good for agriculture. Millions of people in some countries have suffered from a reckless application of industrial organization in 
agriculture. Agricultural production depends upon biological growth processes in plants and animals which can be routinized only within narrow limits. $\mathrm{A}$ close and personal intimate relation between the farmer and his land, crops and livestock is required for efficient production. This makes agriculture a repository of craftmanship within the economic and social pattern of modern society. The individual farmer's attitudes, incentives and motivations play a much more crucial role in agriculture than those of workers in industry. Many of the institutional reforms in industry and commerce, such as corporate finance and bank credit, labor organization and collective wage bargaining, do not fit agriculture. New institutional arrangements must be found which are closely adapted to the peculiar needs of farmers and the nature of the agricultural production process.

4 The requirements for agricultural progress include large capital investments in land improvement and in increasing the intensity of land use and farming systems. To bring these about, changes must be made in the existing pattern of farm sizes, in the location of residence of farm families, in the lay-out of farms, in roads and other communal facilities, and in tenure arrangements. The re-opening of the settlement frontier cases the adjustment problems encountered in old agricultural areas by making land available for the enlargement of undersized holdings and by creating new settlement opportunities for farm families displaced from the old areas. In all these adjustments the governments are called upon to play an active role. For this reason it is all the more important that these policies are formulated and executed in a democratic spirit with the ultimate aim of serving the needs and aspirations of the individual farm family.

5 Resettlement programs represent a major operation in the existing structure of farm sizes, field lay-outs and tenure arrangements. One of their main purpose should be the enlargement of undersized farms into viable units supporting farm families at a decent living standard. This places a responsibility on the government to assist displaced families to move elsewhere within agriculture or into another occupation. Consolidation of fragmented holdings, land improvement, credit and cooperative services for intensifying land use and farming systems, enlargement of undersized farms - they all should be parts of a comprehensive and well-balanced resettlement program. Safeguards should be provided for assuring the continuance of a good farm size pattern and tenure structure once it has been achieved, by measures for preventing subdivision of holdings into non-viable units through inheritance, accumulation of large tracks of land in single hands, and land speculation.

6 Subdivisions of large estates always involve resettlement problems. Usually, the number of people demanding land is greater than can be accommodated on viable farm units. Selection of settlers and farm sizes should not be determined solely on grounds of technical efficiency; human and socio-political considerations must also be recognized. Strong arguements can be made for establishing upper and lower limits of size of holdings, but these limits should be wide enough to allow for diversity in farm sizes commensurate with differences in sizes and capacities of farm families. Such size limits should be based upon gross product value under average management and appropriate farming systems rather than fixed surface areas of land.

7 In a number of countries, interest is growing in cooperative farming as a means to overcome the dis-economies of scale hampering progress on undersized farms, and to bring about a more rapid rate of adoption of modern production techniques through central management than appears possible under conditions of individual farm holdings. In many cases, there is real danger that these advantages might be more than offset, by the disadvantages of employee-employer relations, impersonalization of attitudes toward the work, weakening of incentives and motivational forces, and other aspects of such large-scale industrial types of organization which are most difficult to adapt successfully to the nature of agricultural production processes.

8 Among the most powerful conditions determining the attitudes and motivations of farmers are the tenure arrangements under which they have to live and work. Hence, resettlement programs should strive to establish tenure arrangements which are conductive to mobilize human energies and motivations, to synchronize the interests of the individual with those of the community as much as possible, and to foster the development of managerial skills, the willingness and ability to assume responsibilities of leadership and participation in cooperative and community affairs. 